\title{
The Effect of Growth and Development on the Composition of Mammals
}

\author{
By CHIRISTINE M. SPRAY AND ELSIE M. WIDDOWSON \\ Medical Research Council Department of Experimental Medicine, \\ University of Cambridge
}

(Received ro Fune 1950)

It is a well-known fact that the chemical composition of an animal body is not fixed and constant, but changes throughout life from conception until death. During the active growing period the percentage of fat generally increases, while the percentage of water decreases. It has been suggested (Moulton, 1923) that, if the fat-free composition is considered, there comes a point when the concentrations of watcr, protein and ash become more or less stationary and after which no further appreciable changes take place. Moulton described this as the state of 'chemical maturity'.

Workers in many different fields have traced these changes in composition. von Bezold ( 1857,1858 ), one of the first to be interested in the subject, investigated the chemical composition not only of mammals, but also of birds, amphibians, fish and Crustacea at various stages of development, and from his findings he was able to make generalizations which are just as true to-day as they seemed to him nearly roo years ago. I He found that in mammals, birds and amphibians there was a decrease in the percentage of water until full maturity, and an increase in organic material which was most rapid in the first period after birth or hatching. He also found that the fixed base per unit of body-weight was the same for all vertebrates, that the ratios of potassium to sodium, and of phosphorus to calcium and magnesium in adult animals were very similar, and that growth, both before birth and after, involved a great increase in the concentration of phosphorus, calcium, magnesium and iron in all species.

Inaba (I II I) also analysed a number of different types of animal life, including newborn and adult mice and rats. He came to the conclusion that animals similar morphologically have a similar composition and that warm-blooded animals have a greater proportion of fat in their bodies than those which are cold-blooded.

'The chemical composition of the rat has received much attention. Hatai (1917) and Chanutin (I93I) analysed rats at various stages of growth from birth to maturity for water, protein, fat and ash. The increment of dry matter in the rat was measured by lowrey (I9I3), and the effects of different diets on the composition of males and females were studied by Deucl, Hallman, Movitt, Mattson \& Wu (1944).

Changes in the chemical composition of the pig with increasing weight and age were described by Ellis \& Hankins (1925), Mitchell \& Hamilton (1929), Scott (1930), McMeekan (1940, 1941) and Callow (1948). Hutchinson (1947a, b) and Hutchinson \& Baker (1949) made a detailed investigation of the effect of various diets on the proportions of protein, fat and dry matter in the bodies of domestic rabbits; they showed that, although the growth curves were similar whether the animals were reared on weeds or on potatoes and hay, the bodies of the potato-fed group contained much more 
fat than those of the others. A considerable amount of work has been done on the composition of other farm animals during growth, especially with regard to fattening or flesh production (Moulton, Trowbridge \& Haigh, 1922; Murray, 1922; Hammond, I932; Pálsson, 1939, I940; Callow, 1947, 1948).

Thomas (1911) followed the changes in the amounts of water, protein, fat and ash in the bodies of puppies and kittens during the period immediately after birth while the animals were doubling their birth weights, and McCance (1944) correlated the chemistry of growth of the eel with events taking place in the body, and compared and contrasted it with similar and dissimilar changes in the chemistry of growth of the higher vertebrates.

Many other investigators have described changes in particular organs or constituents. Skeletal development has been one of the most popular. Bone growth and the composition of bone ash have been studied chiefly in the rat (Hammett, 1925; Outhouse \& Mendel, I933; Bessey, King, Quinn \& Sherman, 1935; Zucker \& Zucker, 1946; Carttar, McLean \& L'rist, I950), but also in kittens and pups (Burns \& Henderson, 1936) and in other species (Morgulis, 1931). Calcium, phosphorus and magnesium concentrations in the whole body of the rat were investigated by Buckner \& Peter (1922), Sherman \& Macl ceod (1925), Sherman \& Quinn (1926), Sherman \& Booher (I93I), Cox \& Imboden (1936), I aanford, Campbell \& Sherman (1941) and Briwa \& Sherman (194I).

Bunge's (1889, 1892) pioneering work on suckling anaemia has led to papers on the same subject by Smythe \& Miller (1928-9), Lintzel \& Radeff (I93 I), Foot \& Thompson (1938, 1947), Braude \& Foot (1946), Venn, McCance \& Widdowson (1947), Huggett \& Widdas (1949), McCance \& Widdowson (1951 $a$ ). The influence of sex on the amount of iron in the whole body or in the blood and storage organs has been followed by Steenbock, Semb \& Van Donk (1936), Hubbell \& Rose (1937), Otis \& Smith (1940) and Widdowson \& McCance (1948).

The discovery of the necessity for certain trace elements in the promotion of healthy growth stimulated work on their concentrations in the growing body. Lorenzen \& Smith (1947) found both species and age to affect the percentage of copper and manganese in the body. Copper metabolism in the rat was studied also by Iindow, Peterson \& Steenbock (1929) and Houk, 'Thomas \& Sherman (1946), and Cunningham (I93I) compared the amounts of copper in the organs of many different mammalian species. The bodies and livers of animals throughout the growth period have been analysed for zinc by Fairhall (1926), Lutz (1926), Drinker, Thompson \& Marsh (1927), Hubbell \& Mendel (1927), Bertrand \& Brandt-Beauzemont (193I), Newell \& McCollum (1933) and Sheline, Chaikoff, Jones \& Montgomery (1943).

'The present investigation forms part of a study of some chemical aspects of growth and development. Mice, guinea-pigs, rats, rabbits, cats and pigs were analysed at birth and at the end of the suckling period, and the composition of the last four of these species was followed through to maturity. Data for the human foetus and infant have been presented by Widdowson \& Spray (195I) and for the human adult by Widdowson. McCance \& Spray (195I). 
EXPERIMENTAL

\section{Animals and tissues examined}

Mice. Adult albino males and females were obtained from the colony reared in the Department of Pathology, Cambridge. Mice were bred from these in our own Department, the mothers and families being housed in wooden boxes with wire-mesh lids. 'The pregnant and lactating females received a stock diet consisting of a mixture of bread, yeast, whole wheat, oat flakes, bran. fish meal, wheat germ and dried milk,

Table I. Numbers of mice, rats, guinea-pigs, rabbits, cats and pigs analysed

\begin{tabular}{|c|c|c|c|c|}
\hline \multirow[b]{2}{*}{ Species } & \multirow{2}{*}{$\begin{array}{c}\text { Age } \\
\text { (days) }\end{array}$} & \multicolumn{2}{|c|}{ No. analysed } & \multirow[b]{2}{*}{ How analysed } \\
\hline & & Male & Female & \\
\hline Mouse & $\begin{array}{r}0 \\
15 \\
30\end{array}$ & $\begin{array}{l}34 \\
18 \\
21\end{array}$ & $\begin{array}{l}35 \\
13 \\
18\end{array}$ & Pooled, males and females together \\
\hline Kat & $\begin{array}{r}0 \\
15 \\
30 \\
50 \\
70 \\
90 \\
120 \\
150 \\
200 \\
246 \\
321\end{array}$ & $\begin{array}{r}34 \\
\times 3 \\
6 \\
6 \\
6 \\
6 \\
5 \\
5 \\
6 \\
6 \\
6\end{array}$ & $\begin{array}{r}34 \\
13 \\
6 \\
7 \\
6 \\
7 \\
7 \\
7 \\
6 \\
6 \\
6\end{array}$ & Pooled, males and females separately \\
\hline Guinea-pig & $\begin{array}{r}0 \\
\times 5\end{array}$ & $\begin{array}{l}5 \\
3\end{array}$ & $\begin{array}{l}5 \\
2\end{array}$ & Pooled, males and females together \\
\hline Rabbit & $\begin{array}{r}0 \\
15 \\
35 \\
70 \\
120 \\
180 \\
250\end{array}$ & $\begin{array}{l}8 \\
4 \\
3 \\
3 \\
2 \\
1 \\
1\end{array}$ & $\begin{array}{l}4 \\
7 \\
3 \\
2 \\
2 \\
2 \\
1\end{array}$ & Pooled, males and females separately \\
\hline Cat & $\begin{array}{c}0 \\
21 \\
42 \\
84 \\
126 \\
\text { Aduit }\end{array}$ & $\begin{array}{l}2 \\
1 \\
2 \\
2 \\
1 \\
I\end{array}$ & $\begin{array}{l}3 \\
2 \\
3 \\
1 \\
1 \\
2\end{array}$ & Individually \\
\hline Pig & $\begin{array}{r}0 \\
21 \\
56 \\
112 \\
168 \\
259\end{array}$ & $\begin{array}{l}7 \\
7 \\
3 \\
2 \\
1 \\
1\end{array}$ & $\begin{array}{l}9 \\
3 \\
1 \\
1 \\
I \\
I\end{array}$ & Individually \\
\hline
\end{tabular}

with liver once a week. They were also given fresh whole milk each day. No mother was allowed to rear more than eight young in any one litter. The young began eating solid food at 15 or 16 days. Analyses were made at birth and at 15 and 30 days. The numbers of animals used are given in 'Table 1 . Pooled samples were used at each age and males and females were analysed together. 
Rats. Black-and-white hooded rats from our own colony were used, all offspring of females without previous pregnancies. The stock diet was the same as that given to the mice, with the addition of greens every alternate day. For mating, two males were placed in each cage of eight females and removed after 8 days. Although all females did not become pregnant, the method facilitated sampling as all families were born within a few days of each other. The young rats were weighed as soon as possible after birth, and not more than eight returned to any one mother. Weaning began at 15 days and was completed at 2I days. Growth curves were kept throughout the whole of the experiment, every animal being weighed every $4^{\text {th }}$ day of its life. In all, thirty-four litters were involved and the numbers of animals used are given in Table $\mathrm{x}$. As far as possible, males and females were taken from the litters at alternate stages and, except at birth, not more than one rat was taken from a litter at any one stage. Pooled samples were analysed at each age, and males and females were always treated separately.

Guinea-pigs. The mothers had been reared in the Department of Pathology, Cambridge. 'They were kept in wooden hutches, and their food consisted of sugar-beet pulp, bran and oats, with greens twice, and cod-liver oil once, a week. Seven litters were used. Five males and five females were taken at birth and pooled for analysis; three males and two females aged 15 days were also killed and analysed together. As the young are born in such an advanced state of development and begin to eat solid food as early as I day after birth, there is no real 'full' suckling period.

Rabbits. 'The rabbits came from two different sources. The first four families were those of does in the Department of Pathology, Cambridge. For the second series, five does in kindle were obtained and kept by a member of the Department in hutches in her garden. A mixed diet of greens, mangels, sugar-beet pulp, carrots, bran, baked bread and dried milk was given. Weaning of the young began at 15 days, and they left the mother at 30 days. Seven stages in the growth of the rabbit from o to 250 days of age were studied. For the first three of these, several animals were analysed together, but at $70,120,180$ and 250 days each animal was analysed individually and the results were averaged. Males and females were always studied separately. At birth and 15 days, the rabbits used came from all nine litters, but at later stages from only five.

Cats. These animals, whose food consisted of horse-meat, milk and table scraps, were kept by various members of the Department in their own homes.

Cats from five litters were taken at five stages from birth to 18 weeks of age, each animal being analysed individually. For the later stages, mothers of two of these litters were used, both aged I year. One adult castrated male, a fine specimen but of unknown age, was also analysed.

Pigs. These animals were obtained from the Institute of Animal Pathology, Cambridge. They were bred from Large White or first-cross Wessex $\times$ Large White sows which were mated to a Wessex boar. The pigs were kept in concrete pens with covered sties, and were fed on pollards, bean meal and fish meal. Weaning of the young piglets began at the age of 3 weeks and was completed at 8 weeks. The males were castrated when they were 8 weeks old. Seven stages of growth from o to 39 weeks were represented. 'The animals came from nine litters and actual numbers of each sex at each stage are given in Table 1 . 
The effect of giving Fe to piglets reared in clean, concrete sties on their growth and on the Fe content of their bodies was studied by Venn et al. (1947). 'I'hey showed that the administration of $\mathrm{Fe}$ to piglets during the first 3 weeks of life made them take more milk and grow more quickly, and greatly increased the amount of Fe in the body. The piglets used in that investigation were analysed for constituents other than $\mathrm{Fe}$, and the composition of the six animals mentioned in Table VI of the paper of Venn et al. will now be described. Three of these piglets had been given ferrous sulphate in a daily dose of $5 \mathrm{mg}$. Fe/lb. body-weight for 3 weeks; the other three, which were litter-mates of the first three, had received no supplementary Fe. The members of each pair had approximately the same weights at birth and the beneficial effect of the Fe supplement on growth has already been emphasized.

Hedgehogs. Two hedgehogs, found dead, but in good condition, on the roadside were analysed.

Sheep's wool and human hair. One sample of wool from a sheep reared at the Field Laboratories, Cambridge, and four samples of human hair were analysed for zinc.

\section{Chemical methods}

Preparation of carcasses for analysis. 'The smaller animals were usually killed with carbon monoxide, and the pigs, older cats and rabbits with chloroform or by injecting air into the heart of the anaesthetized animal. 'The preparation of the small pigs for analysis has already been described (Venn et al. 1947). The mice, rats, guinea-pigs, rabbits and cats were dissected and digested with hydrochloric acid in a similar way. The large pigs were weighed immediately after death and then dissected. The livers and spleens and all the viscera were removed and the heads cut off. These, with all the blood washings, comprised one sample, which was digested with hydrochloric acid as described by Venn et al. (1947) for the younger animals. The carcass was bisected as nearly as possible by sawing down the vertebral column, and the two portions were weighed to assure an equal division. Both halves were washed free from extraneous blood and these blood washings were added to the first sample. One half only was digested with hydrochloric acid, and after analysis all results were doubled before being added to those for the viscera, head and blood washings.

Total nitrogen was determined on duplicate portions of the acid hydrolysates by the Kjeldahl method using copper selenide as catalyst. Protein was calculated as $\mathrm{N} \times 6.25$.

Fat was estimated in all material by the method of von Lieberman \& Szekely (1898) as described by McCance \& Shipp (1933). Details have been given by Venn $e$ t al. (1947) about the technique adopted for sampling fat bodies.

Water was calculated by difference, due allowance being made for the inorganic constituents (Widdowson et al. 1951).

Phosphorus was estimated by the modification by McCance, Widdowson \& Shackleton (1936) of Briggs's (1922) method, after digesting duplicate portions of the acid hydrolysates with conc. sulphuric and perchloric acids. A solution of I vol. ammonia, sp.gr. 0.88 , in 3 vol. water was used instead of $40 \%$ sodium hydroxide for neutralizing the digested mixture. 
Inorganic iron in the fresh livers and spleens was measurcd with $\alpha \alpha^{\prime}$-dipyridyl as described by Shackleton \& McCance (1936).

\section{Further treatment for determination of metals other than inorganic iron}

General. Duplicate portions of $50 \mathrm{ml}$. of the acid hydrolysates were evaporated to dryness in silica crucibles and incinerated overnight at $450^{\circ}$. Weighed samples of the finely chopped livers were dried and similarly incinerated. The crucibles were allowed to cool, 2.5 or $5 \mathrm{ml}$. of conc. hydrochloric acid were added, and the mixtures were gently evaporated to dryness to ensure that all the iron would be in a soluble form. 'The subsequent extraction of the ash with hydrochloric acid was carried out as described by McCance et al. (1936).

Sodium. The method described by McCance \& Shipp (r933), with the precautions suggested by Harrison ( $195 \mathrm{I})$, was used, but the precipitated sodium zinc uranyl acetate was titrated against $0.02 \mathrm{~N}-\mathrm{NaOH}$ instead of being measured colorimetrically.

Potassium, calcium and magnesium were estimated in the cxtract of the ash as described by McCance \& Shipp (1933).

Total iron in the acid hydrolysates and in the livers was determined by means of thioglycollic acid (McCance et al. 1936).

Copper was estimated colorimetrically with diethyldithiocarbamate by Eden \& Green's ( I940) method.

Zinc was determined colorimetrically with 'dithizone' as described by Keilin \& Mann (1940). For the determination of zinc in human hair and sheep's wool, a dry weighed sample was ashed in a silica crucible at $450^{\circ}$ and the ash subsequently brought into solution in $\mathrm{O} \cdot \mathrm{I} \mathrm{N}-\mathrm{HCl}$.

\section{Presentation of results}

The ideal way of comparing the chemical compositions of the different mammals would be to express graphically the percentages of each constituent at equivalent ages from birth to maturity, but it has been found impossible to express equivalent ages in a linear relationship. Major events in development, e.g. birth and puberty, are differently spaced in the span of life of each species. Moulton (1923) divided the mammals into groups according to the degree of chemical and anatomical development at birth. He pointed out that the pig and cat were relatively mature, the rabbit less so, and the rat least mature of all. Hence birth in the four species cannot be regarded as taking place at an equivalent age. Nor can growth rates be used to determine equivalent ages, since different animals do not necessarily grow fastest at similar stages of development (Brody, 1927).

In view of these difficulties the chemical development of each species is shown separately. The older male pigs and the one adult male cat were castrated, and the figures for males and females in these two species have been put together. With the rats and rabbits, the results for the two sexes are both presented. Table 2 gives some relevant details about the life histories of the six species of animals studied. 
Table 2. Description of species analysed

\begin{tabular}{|c|c|c|c|c|c|c|}
\hline $\begin{array}{l}\text { Species } \\
\text { Class }\end{array}$ & $\begin{array}{l}\text { Mouse } \\
\text { Rodent }\end{array}$ & $\begin{array}{l}\text { Rat } \\
\text { Rodent }\end{array}$ & $\begin{array}{l}\text { Guinea-pig } \\
\text { Rodent }\end{array}$ & $\begin{array}{l}\text { Rabbit } \\
\text { Rodent }\end{array}$ & $\begin{array}{l}\text { Cat } \\
\text { Carnivore }\end{array}$ & $\begin{array}{l}\text { Pig } \\
\text { Ungulate }\end{array}$ \\
\hline $\begin{array}{l}\text { State of maturity } \\
\text { at birth } \quad \ldots\end{array}$ & $\begin{array}{l}\text { Helpless, } \\
\text { blind, } \\
\text { naked }\end{array}$ & $\begin{array}{l}\text { Helpless, } \\
\text { blind, } \\
\text { naked, } \\
\text { short tail, } \\
\text { closed ears, } \\
\text { undeveloped } \\
\text { limbs }\end{array}$ & $\begin{array}{l}\text { Well } \\
\text { developed, } \\
\text { furry, } \\
\text { open-cyed, } \\
\text { able to feed } \\
\text { itself at } \\
\text { I day of age }\end{array}$ & $\begin{array}{l}\text { Helpless, } \\
\text { blind, } \\
\text { naked, } \\
\text { closed ears }\end{array}$ & $\begin{array}{l}\text { Born with } \\
\text { hair, but } \\
\text { blind, } \\
\text { deaf and } \\
\text { helpless }\end{array}$ & $\begin{array}{l}\text { Open-eyed, } \\
\text { active, able } \\
\text { to stand }\end{array}$ \\
\hline \multicolumn{7}{|l|}{$\begin{array}{l}\text { Length of suckling } \\
\text { period: }\end{array}$} \\
\hline Full (days) & 15 & 15 & * & 15 & 42 & 21 \\
\hline $\begin{array}{l}\text { Full and partial } \\
\text { (days) }\end{array}$ & 21 & $2 \mathrm{I}$ & $12-15$ & 30 & 63 & 56 \\
\hline $\begin{array}{l}\text { Birth-weight } \\
\text { increase during } \\
\text { full suckling } \\
\text { (times) }\end{array}$ & $6 \cdot 0$ & 4.7 & * & 3.5 & $5 \cdot 8$ & 4.5 \\
\hline $\begin{array}{l}\text { Age at puberty } \\
\text { (days) }\end{array}$ & $42-56$ & 60 & 120 & 150 & 250. & 120 \\
\hline
\end{tabular}

RESULTS

Body-weights. 'The growth curves of the rat, rabbit, cat and pig are given in Fig. I. Data for the rat and rabbit are most complete because of their comparatively short life spans. A sex difference is clearly seen by the age of 40 days in the rat, but male and female rabbits were similar in weight. 'The exact age of one of three adult cats was not known and the curve which has been drawn between the last two points may not have represented accurately the growth of these particular animals. The growth rate of the pig at 259 days, the last point on the curve, was still rapid, for this animal is not fully grown until the age of 2 years.

Water, fat and protein. Fig. 2 shows the effect of age on the water and fat in the rat, rabbit, cat and pig. The shapes of the two curves for each animal were almost complementary, and the percentage of water in the body clearly depended to a large extent on the percentage of fat. A comparison of the composition of these animals at birth has already been made (Widdowson, 1950) and a comparison at later ages can be made from the data given in Fig. 2. In each of these species birth was followed by a large increase in the percentage of fat in the body, with a corresponding though not equal decrease in that of water. In the rat and rabbit, which are least mature at birth, the fall in water was greater than the rise in fat, and this was probably due to a considerable decrease in the proportion of extraccllular fluids. Table 3 gives data about the composition of mice and guinea-pigs during the early parts of their lives, and the organic changes taking place in the mouse are very similar to those shown in the rabbit in Fig. 2. 'I'he guinea-pig, on the other hand, had about $10 \%$ of fat in its body at birth and this had fallen to $\mathrm{x} \cdot 7 \%$ by the time the animal was $\mathrm{I}_{5}$ days old. The guinea-pigs analysed at I 5 days weighed only 1.4 times as much as litter-mates at birth, and the absolute amount of fat in their bodies was only one-quarter as much at 15 days as it had been a* 

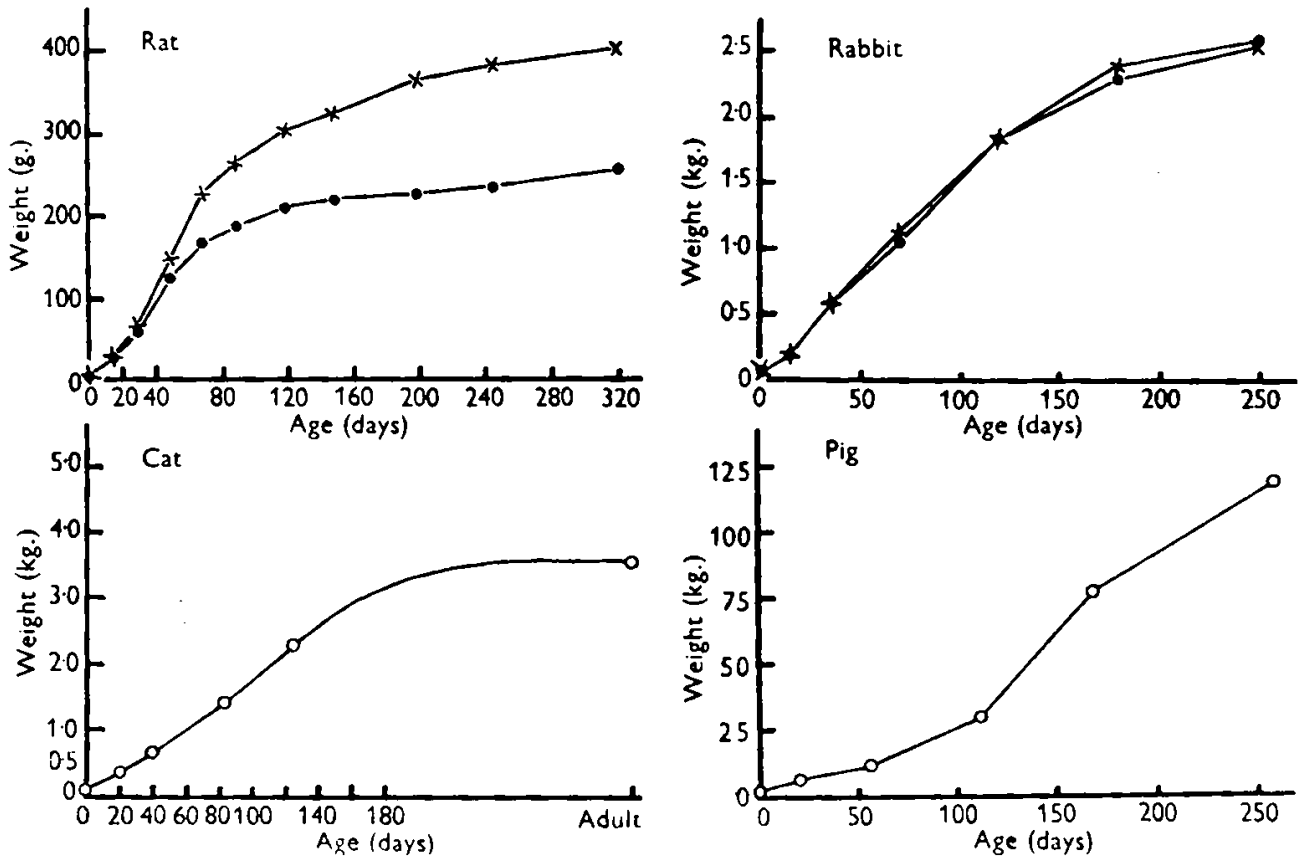

Fig. $x$. Growth curves of rats, cats, rabbits and pigs throughout the experimental period. $x-x$, males; - - , females; $O-O$, males and females mixed. Table $I$ gives the number of animals on which values are based.
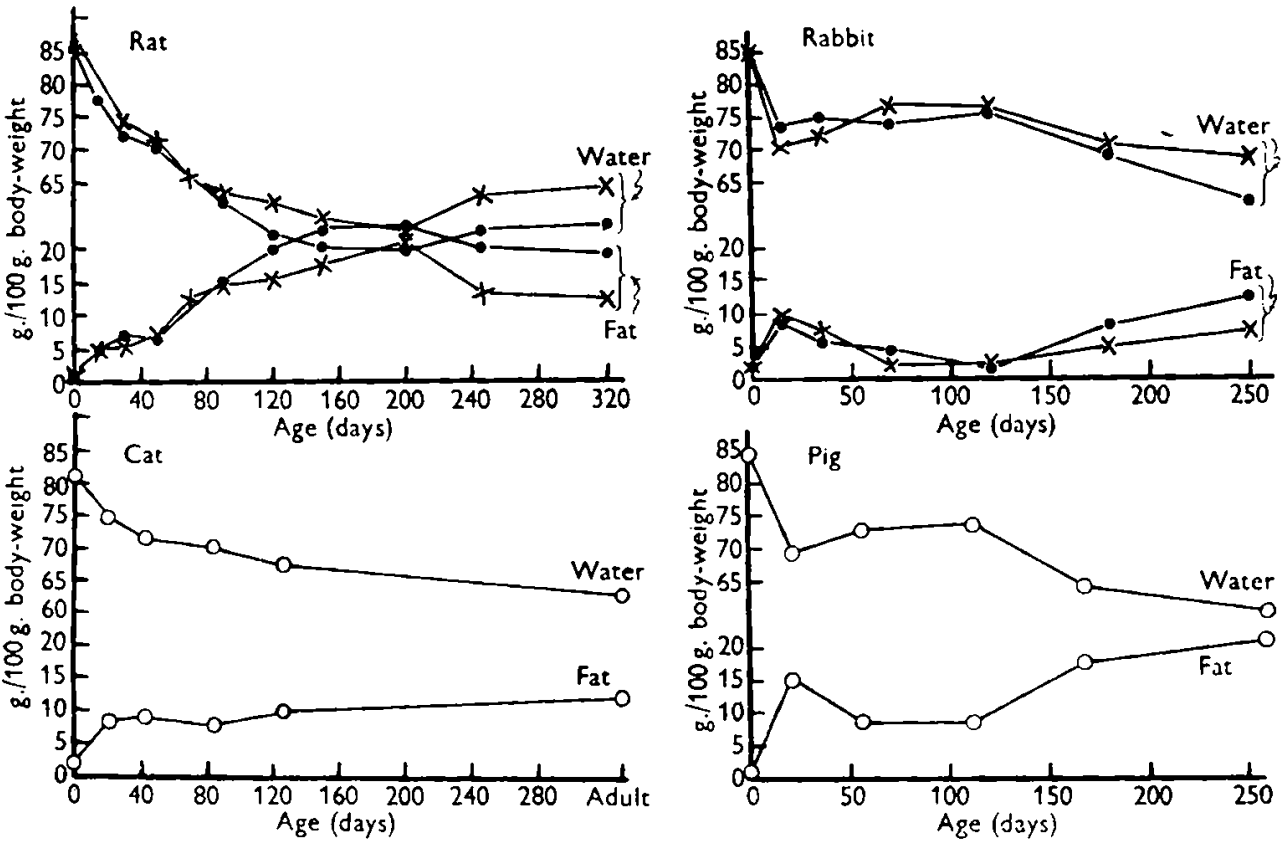

Fig. 2. Effect of age on the proportions of fat and water in the bodies of rats, cats, rabbits and pigs. $x \rightarrow x$, males; - - , females; $O-O$, males and females mixed. 'Table $I$ gives the number of animals on which values are based. 


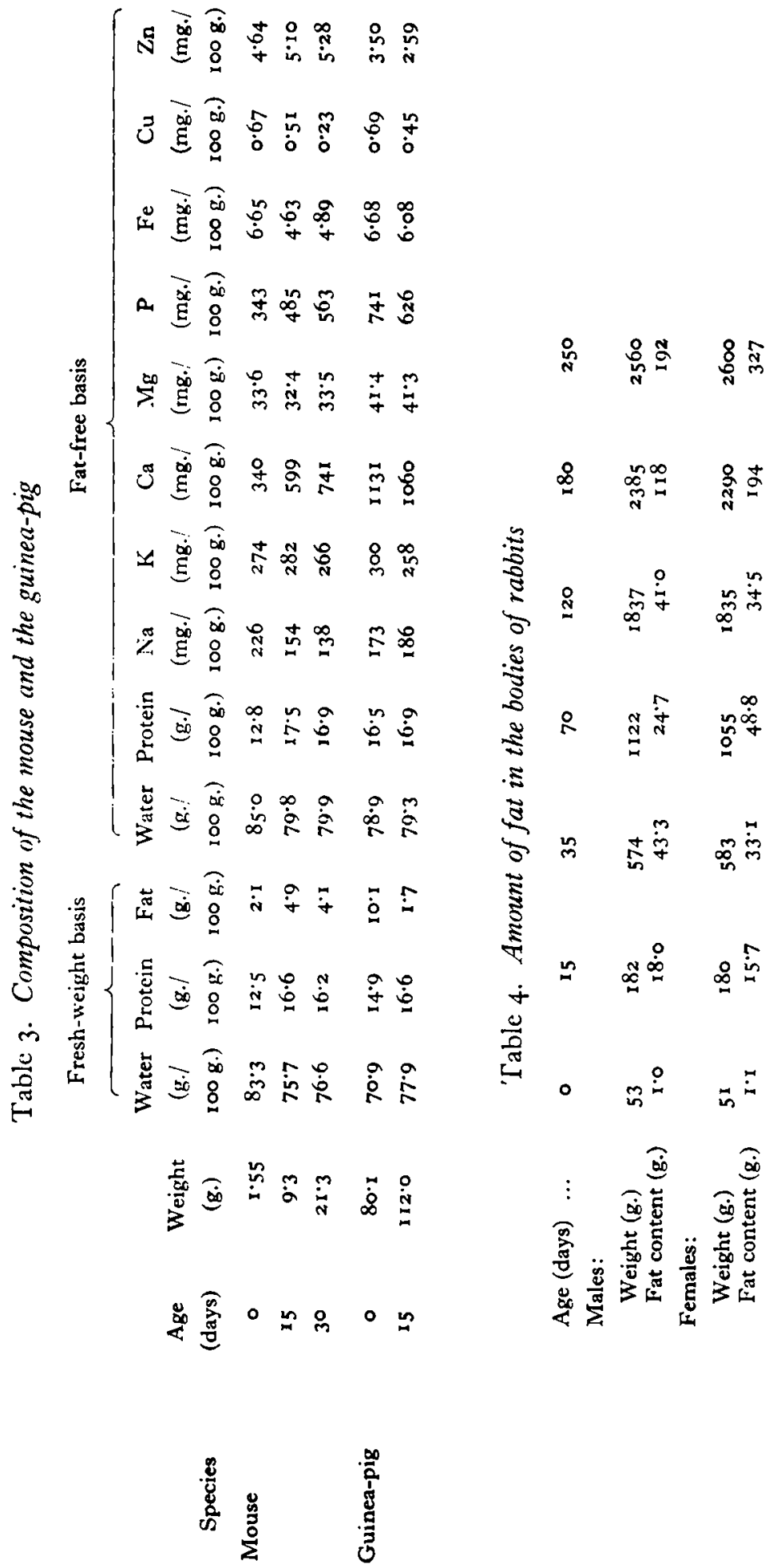


birth. The concentration of fat in the guinea-pig was then lower than that in any other species at the same age. The proportion of water increased in these 15 days by $7 \%$. The guinea-pig is able to eat food other than milk from the Ist day onwards, and the diet rather than the activity is probably the chief reason for this fall in fat. The young pig is also very active and it showed a greater increase in fat than any of the other species during the time it was nourished solely on milk, but when it was weaned there was a decrease in the percentage of fat in its body also. Similar observations were made on the rabbit. In the rat there was merely a reduction in the rate at which fat was being deposited. In all species except the guinea-pig and the rabbit the total amounts of fat in the body continued to increase throughout. After the adjustments to the changed diet at weaning had been made, the process of fattening was resumed. With the rabbit, a notoriously lean animal, the second increase in the concentration of fat took much longer to begin than in the rat, cat or pig. At 120 days the percentage of fat in the rabbit was almost exactly the same as it had been at birth and the total amount in the body fell for a time in both sexes (Table 4).

Female rats at 200 days contained $23.7 \%$ fat. This appears to be the upper limit for the species, since the percentage fell in the older animals. The two final figures of 13.4 and $12.8 \%$ for male rats at 246 and 321 days respectively are similar to the figure of $13.4 \%$ reported by Chanutin (1931) for adult animals. Hatai (1917) found only $5.7 \%$ fat in rats aged 294 days. The percentage of fat in the bodies of rabbits, cats and pigs was still increasing when the observations came to an end. Larger figures for the pig would undoubtedly have been obtained if older animals had been analysed. Callow (1948) reported a value of $59 \%$ in a hog 46 weeks old and weighing $156 \mathrm{~kg}$.

Donaldson (1924) and Deuel et al. (1944) reported that female rats contained more fat per $100 \mathrm{~g}$. body-weight than male rats of the same age. 'The present work has confirmed these observations and shown that this difference becomes apparent at the age of 90 days, i.e. approximately I month after the onset of puberty. In the rabbit puberty itself marked the beginning of the period in which the females became fatter than the males.

Fig. 3 gives the data for water and protein in the bodies of the rat, rabbit, cat and pig on a fat-free basis. When these curves for water are compared with those of Fig. 2 it will be seen that they are much more regular with the disturbing effect of fat removed. In each of the four species there was a rapid decrease in the proportion of water during the early stages of postnatal life and this was followed by a period when the change became very slow until an almost constant percentage was reached at the point of chemical maturity. The stability was most clearly demonstrated in the rat.

The changes in protein were the reciprocal of those for water. The biggest increase took place during the suckling period. Thereafter the increase became slower until the protein in the rat, rabbit and cat reached a concentration of $21.0-24.5 \%$. It is probable that the protein in the pig would also have reached this level had older animals been analysed. 'The results shown here for the percentage in the growing rat are all slightly lower than those given by Chanutin (I93 I), but the curve is of very similar shape to his and a constant percentage was reached at the same age, about 100 days. The figures here given for pigs are in quite good agreement with those collected by Moulton (1923). 
When the curves for water and protein are presented on a fat-free basis there is an almost complete elimination of sex variation in the rat and rabbit. So far as protein, fat and water are concerned, growth in the two sexes therefore is similar except for a greater deposition of fat by the female.
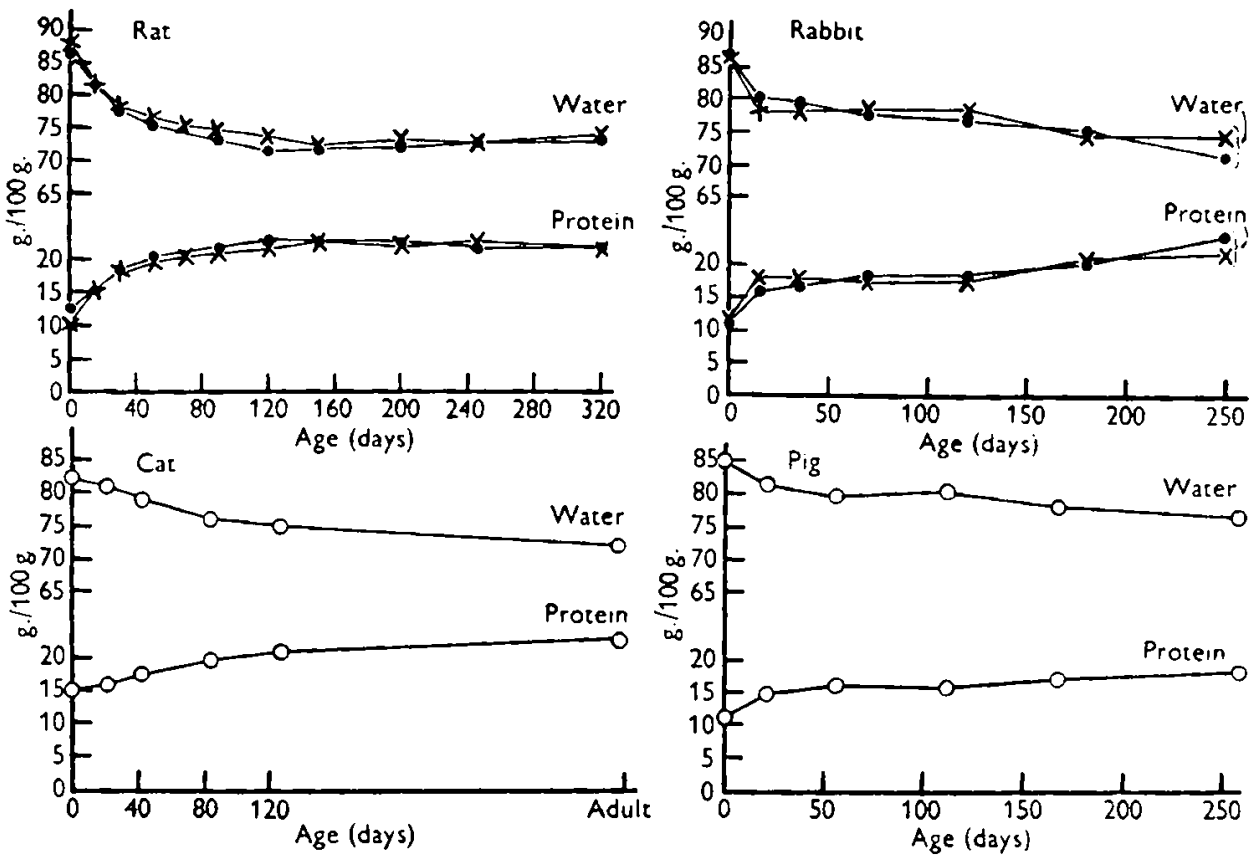

Fig. 3. Effect of age on concentrations of water and protein in fat-free body tissue of rats, cats, rabbits and pigs. $x-x$, males; $\rightarrow$, females; $O-O$, males and females mixed. Table 1 gives the number of animals on which values are based.

Sodium and potassium. The concentrations of $\mathrm{Na}$ and $\mathrm{K}$ in the growing animals are shown in Fig. 4. In all four species there was more $\mathrm{Na}$ than $\mathrm{K}$ in the body at birth, but the concentration of $\mathrm{Na}$ in the fat-free body tissue decreased rapidly while that of $\mathrm{K}$ rose, so that when the animals were a week or so old they had approximately equal amounts of the two bases. Sodium continued to fall and $\mathrm{K}$ to rise until an almost constant level was reached which marked 'chemical maturity' with regard to these two elements. At this stage the concentration of $\mathrm{K}$ was about twice that of $\mathrm{Na}$ in all the species. Male and female rats and rabbits had similar proportions of $\mathrm{Na}$ and $\mathrm{K}$ per Ioo g. of fat-free body tissue.

Calcium, phosphorus and magnesium. 'The data for $\mathrm{Ca}, \mathrm{P}$ and $\mathrm{Mg}$ are given together in Fig. 5. 'The curves show striking species differences, especially in the changes in $\mathrm{Ca}$ concentration from birth to maturity. The mouse (Table 3), rat and rabbit are similar in that all begin extra-uterine life at a low level of calcification. The newborn mouse and rat contained only $300-350 \mathrm{mg}$. $\mathrm{Ca} / \mathrm{r} 00 \mathrm{~g}$. and the rabbit had approximately $480 \mathrm{mg}$. In all three species a large increase in Ca concentration took place during the suckling period, after which the rate of accretion gradually fell until the percentage characteristic of maturity was reached. This occurred in the rat at about 100 days and 

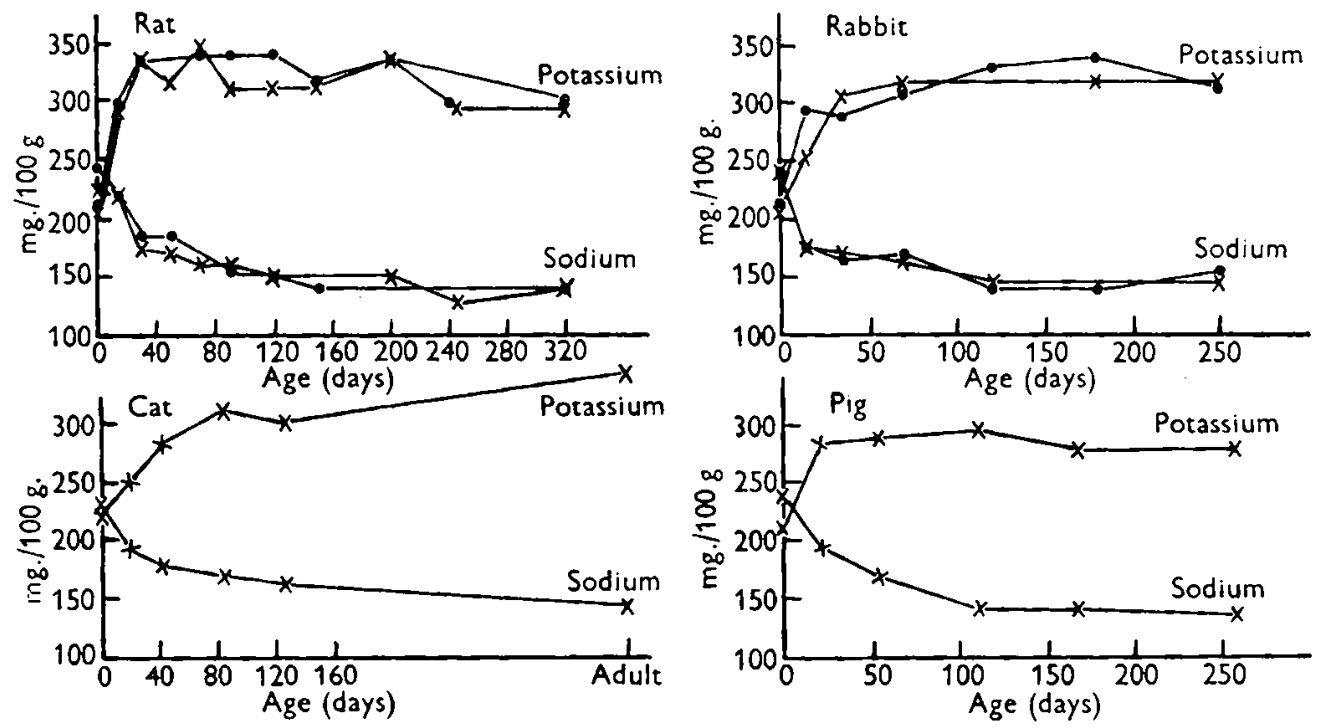

Fig. 4. Effect of age on the concentrations of sodium and potassium in fat-free body tissue of rats, cats, rabbits and pigs. $\times-x$, males; $-\bullet$, females. Table $I$ gives the number of animals on which values are based.
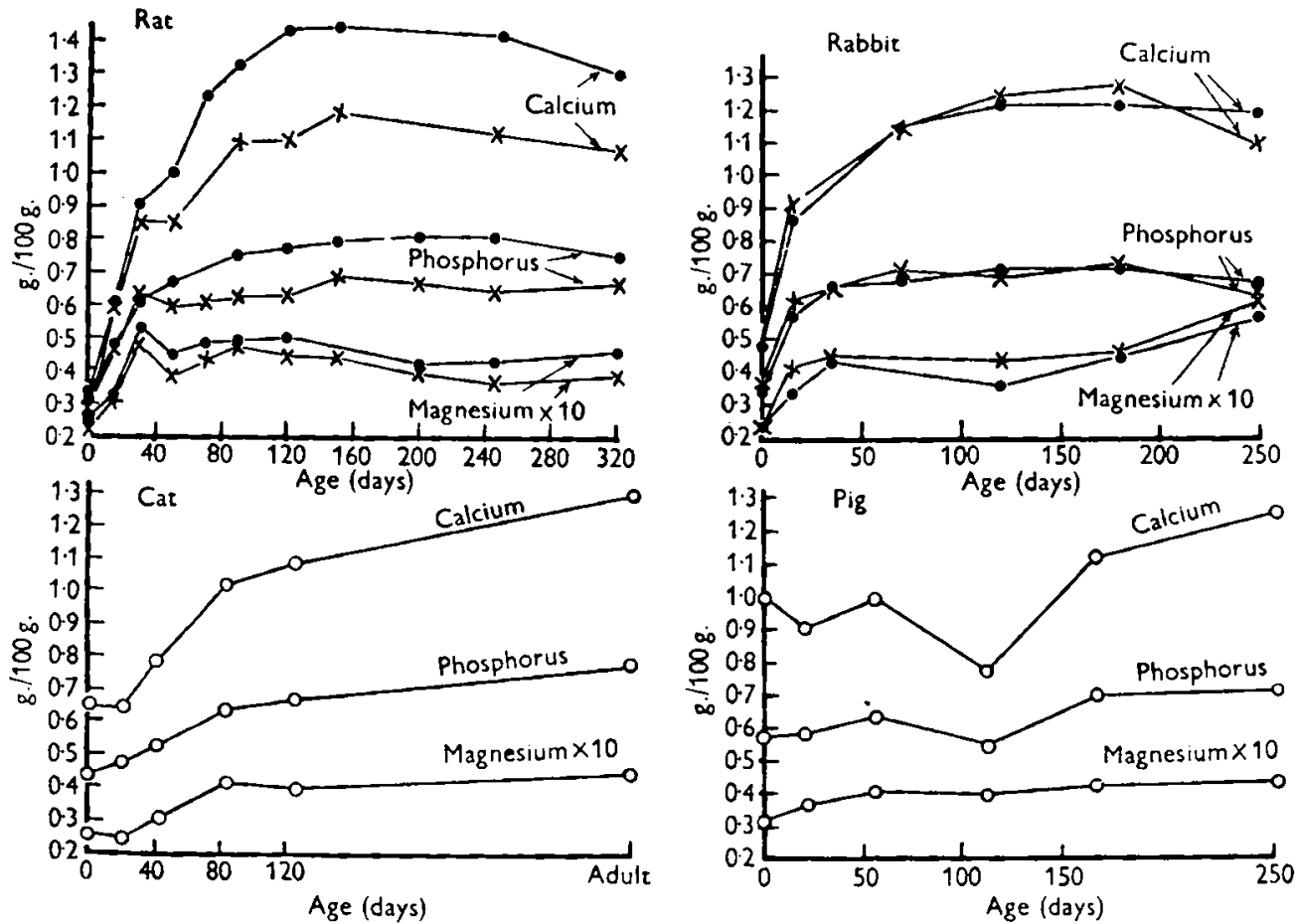

Fig. 5. Effect of age on the concentrations of calcium, magnesium and phosphorus in fat-frec body tissue of rats, cats, rabbits and pigs. $x-x$, males; -0 , females; $0-0$, males and females mixed. Table I gives the number of animals on which values are based. 
in the rabbit in the region of 80 days. The mouse was not studied after the age of 30 days. Hammett ( 1925 ), in his work on bone growth in the albino rat, detected a drop in growth capacity of the humerus and femur at 30 days which he attributed to adjustment to new feeding conditions following weaning. This observation can now be supported by changes in the rate of $\mathrm{Ca}$ accretion.

The shape of the curve for $\mathrm{Ca}$ in the growing pig is different from that in the rat and rabbit, and the curve for $\mathrm{Ca}$ in the cat lies somewhere between the two. At birth the pig contained more than three times as much $\mathrm{Ca} / \mathrm{I} / 00 \mathrm{~g}$. as the rat and had $\mathrm{r} \%$ of $\mathrm{Ca}$ in the fat-free tissue. By the time it was $\mathrm{I} 6$ wecks old it had only $0.7-0.8 \%$; the concentration then rose quickly to a level comparable with that of the adult rat and rabbit. The newborn guinea-pig contained more $\mathrm{Ca} / \mathrm{ro0} \mathrm{g}$. than any of the other species studied ('Table 3) and there was a small decrease in this concentration during the first $x_{5}$ days of its life. The cat was not so well calcified as the pig or guinea-pig at birth but was considerably more so than the mouse, rat and rabbit. A slight initial fall in Ca concentration may have taken place in the days following birth, but by the end of weaning at the age of 6 weeks a substantial increase had taken place. Thereafter, the curve resembled those for the rat, rabbit and pig.

Sherman \& Booher (1931) and Lanford et al. (1941) have shown that the amount of $\mathrm{Ca}$ in the body of the growing rat depends upon the $\mathrm{Ca}$ content of the diet. It is possible that the drop in the concentration of $\mathrm{Ca}$ in the pig between the end of suckling and the age of $\mathrm{I} I 2$ days was caused by a deficiency of $\mathrm{Ca}$ in the diet. During this period the weight increased five times and, though the diet received by these particular animals was considered adequate for normal growth, it clearly did not contain enough $\mathrm{Ca}$ and/or vitamin $\mathrm{D}$ to maintain full calcification. It would be interesting to discover if the level of $\mathrm{Ca}$ at birth could be maintained by changing, or adding to, the diet.

It is known that $\mathrm{Ca}$ reaches a higher concentration in the bodies of female than of male rats. Hammett (1925) reported that the humerus and femur of the female rat contained a higher proportion of ash than the corresponding bones of the male from the age of 23 days, and 'Zucker \& Zucker (1946) noted that the femurs of female rats were better calcified than those of males from the time the animals weighed $3 \circ \mathrm{g}$. Sherman \& MacLeod (1925) and Deuel et al. (1944), who analysed the whole bodies of rats, also found sex differences. In the present work the female rats contained more $\mathrm{Ca} / \mathrm{roo} \mathrm{g}$. than the males from the age of $I_{5}$ days, i.e. when the animals weighed about $3 \circ \mathrm{g}$. A difference between the sexes was not so apparent in the rabbits.

Phosphorus increased with $\mathrm{Ca}$ and the curves for these two elements resemble each other, but differ to some extent because of the large amounts of $P$ in the soft tissues. Sherman \& Quinn (1926) found that the intake of $\mathrm{Ca}$ was the limiting factor in the storage of both $\mathrm{Ca}$ and $\mathrm{P}$ in the rat. This may explain why the $\mathrm{P}$ concentration in the pig did not begin to increase until the $\mathrm{Ca}$ did at the age of $\mathrm{I} I 2$ days. The $\mathrm{Ca}: \mathrm{P}$ ratios in the rat, rabbit, cat and pig throughout growth are given in 'Table 5. In all four species the final values were approximately the same, i.e. $1 \cdot 7-\mathrm{I} \cdot 8$, and this is also the figure given by Widdowson et al. (195I) for the adult man. 'The rat and rabbit, which are so poorly calcified at birth, started their lives with a low $\mathrm{Ca}: \mathrm{P}$ ratio, but by the time 
Table 5. Calcium: phosphorus ratio of the rat, rabbit, cat and pig

\begin{tabular}{|c|c|c|c|c|c|c|}
\hline \multirow[b]{2}{*}{ Species } & \multirow[b]{2}{*}{$\begin{array}{c}\text { Age } \\
\text { (days) }\end{array}$} & \multicolumn{2}{|c|}{ Calcium : phosphorus ratio } & \multirow[b]{2}{*}{ Species } & \multirow[b]{2}{*}{$\begin{array}{c}\text { Age } \\
\text { (days) }\end{array}$} & \multirow[b]{2}{*}{$\begin{array}{c}\text { Calcium: phosphorus } \\
\text { ratio }\end{array}$} \\
\hline & & For the male & For the fernale & & & \\
\hline \multirow[t]{9}{*}{ Rat } & 0 & 0.91 & 0.93 & Cat & o & $I \cdot 52$ \\
\hline & I 5 & $1 \cdot 27$ & $1 \cdot 28$ & & $2 \mathrm{I}$ & $1 \cdot 37$ \\
\hline & 30 & - & $I \cdot 49$ & & 42 & $I \cdot 50$ \\
\hline & 50 & $1 \cdot 43$ & $I \cdot 5 I$ & & 84 & $1 \cdot 60$ \\
\hline & 90 & $1 \cdot 76$ & $1 \cdot 77$ & & 126 & $1 \cdot 60$ \\
\hline & 120 & $1 \cdot 75$ & $\mathrm{I} \cdot 86$ & & Adult & $1 \cdot 66$ \\
\hline & 150 & $1 \cdot 71$ & $1 \cdot 82$ & Pig & 0 & $1 \cdot 74$ \\
\hline & 246 & $\mathrm{r} \cdot 75$ & $1 \cdot 76$ & $1_{15}$ & 2 I & $1 \cdot 55$ \\
\hline & 321 & $x \cdot 6 I$ & $\mathrm{I} \cdot 74$ & & 56 & $1 \cdot 57$ \\
\hline \multirow[t]{6}{*}{ Rabbit } & $\circ$ & $I \cdot 3 I$ & $I \cdot 42$ & & 112 & $1 \cdot 42$ \\
\hline & 15 & $I \cdot 48$ & $1 \cdot 51$ & & I 68 & $1 \cdot 60$ \\
\hline & 70 & $1 \cdot 61$ & $I \cdot 68$ & & 259 & $1 \cdot 75$ \\
\hline & 120 & $\mathbf{I} 79$ & $I \cdot 69$ & & & \\
\hline & 180 & $I \cdot 75$ & $1 \cdot 69$ & & & \\
\hline & 250 & $I \cdot 73$ & $1 \cdot 77$ & & & \\
\hline
\end{tabular}

they were about 90 days old the ratio had reached the adult level. 'The $\mathrm{Ca}: \mathrm{P}$ ratio in the pig, which was $1 \cdot 7$ at birth, fell during the first 16 weeks and then rose again.

The adult animals in all four species contained approximately the same concentration of $\mathrm{Mg}, 45 \mathrm{mg} . / 100 \mathrm{~g}$. of fat-free tissue. This is in excellent agreement with the findings of Widdowson et al. (1951) for the proportion of $\mathrm{Mg}$ in the adult human body; Morgulis (I93 I) found that the percentage of $\mathrm{Mg}$ in the bones varied little in many species. To a certain extent $\mathrm{Ca}$ and $\mathrm{Mg}$ varied together, and the animals that were most highly developed at birth, the pig and guinea-pig, contained most $\mathrm{Mg}$ as well as most $\mathrm{Ca}$. The rabbit was peculiar in that the concentration of $\mathrm{Mg}$ increased considerably between $\mathrm{I} 80$ and $25^{\circ}$ days, although $\mathrm{Ca}$ and $\mathrm{P}$ fell slightly over the same period. Variations in the concentrations of $\mathrm{Mg}$ from one species to another were, however, much smaller than those of $\mathrm{Ca}$, and the pig, for example, which had more than three times as much $\mathrm{Ca}$ as the rat at birth, had only one-third more $\mathrm{Mg}$.

Iron. Fig. 6 shows the effect of age on the concentrations of Fe in the bodies of the rat, rabbit, cat and pig. In the rat the fall during suckling (McCance \& Widdowson, I $95 \mathrm{I} a$ ) was replaced by a gain when mixed feeding began, and the concentration in the males was as high by the 8oth day as it had been at birth, and remained at about $5.5 \mathrm{mg}$. I $00 \mathrm{~g}$. of fat-free body tissue for the rest of the animal's life. The concentration in the female rose more steeply after suckling and reached a level of about $7 \mathrm{mg} . / \mathrm{I} 00 \mathrm{~g}$. at the age of 200 days. Although the deposition of inorganic Fe in the liver was responsible for most of this increase, the extra-hepatic tissues of the adult female contained a higher concentration of $\mathrm{Fe}$ than those of the adult male ('Table 6).

The rabbit did not regain the extraordinarily high $\mathrm{Fe}$ concentration with which it was born. After the end of suckling, the figures for female rabbits were never below those for the males, but the differences were small. 'The concentration of $\mathrm{Fe}$ in the livers of female rabbits was no higher than in male rabbits of the same age (Widdowson \& McCance, 1948), so that in this species any sex difference in the concentration of Fe in the whole body must have been due to a difference in the extra-hepatic tissues. 
After recovery from suckling anaemia, the cat showed no further rise in the concentration of $\mathrm{Fe}$ in its body, but a steady and continuous increase in the $\mathrm{Fe}$ concentration took place in the pig up to the age of 37 weeks. It is impossible to predict the level in this species at full maturity. The distribution of $\mathrm{Fe}$ in the bodies of cats and pigs has been discussed by McCance \& Widdowson (195 I $a$ ).
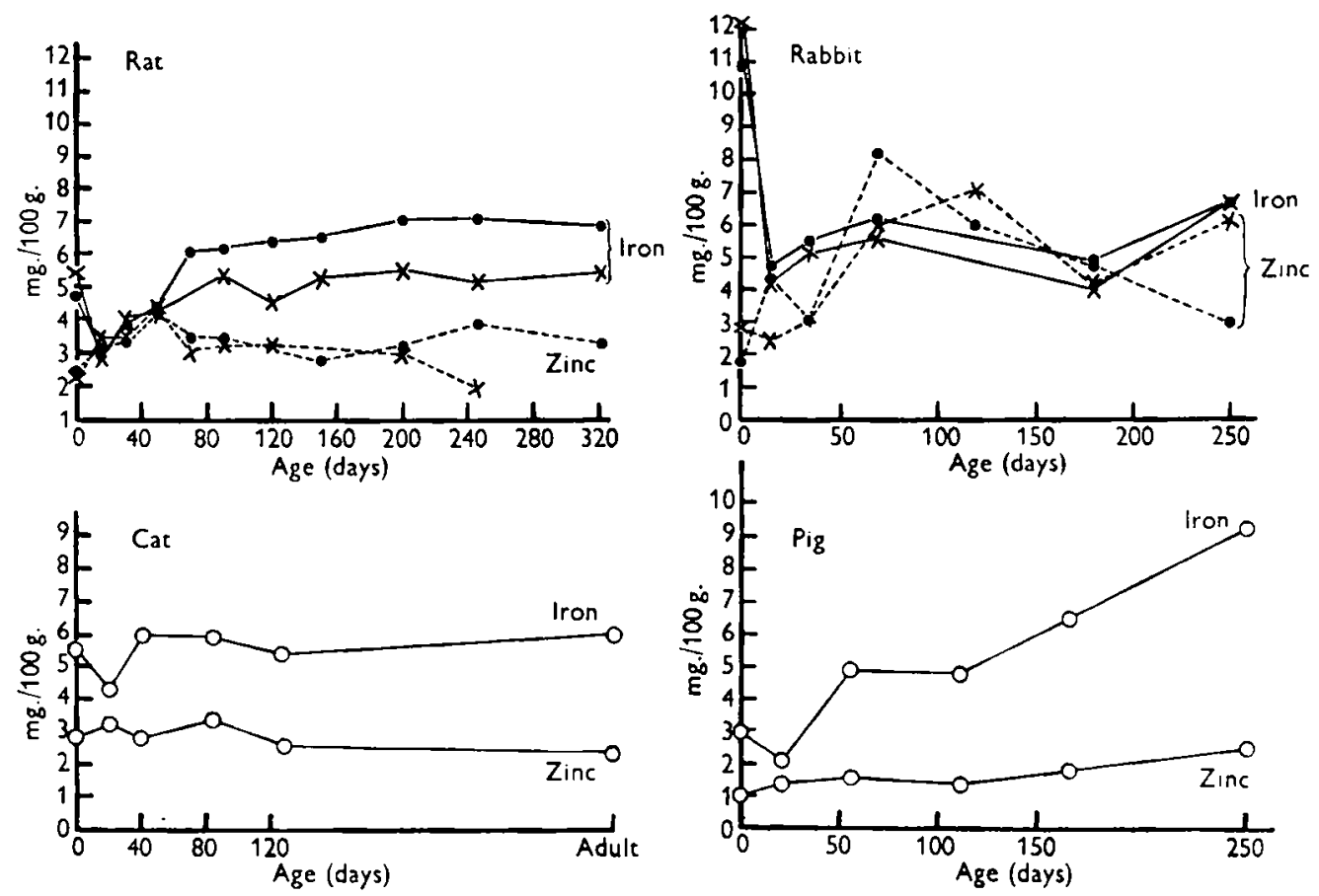

Fig. 6. Effect of age on the concentrations of iron and zinc in fat-free body tissue of rats, cats, rabbits and pigs. $\times-\times$, males; - , females; $\bigcirc-0$, males and females mixed. Table 1 gives the number of animals on which the values are based.

Zinc. The concentrations of $\mathrm{Zn}$ in the whole bodies of the animals are also shown in Fig. 6; there are irregularities, but the main trends are clear. In the rat and the rabbit a considerable increase in $Z_{n}$ concentration took place during the early stages of growth, and this was followed by a fall. There was little change in the proportion of $\mathrm{Zn}$ as cats and pigs grew from birth to maturity. 'The general level was highest in the rabbit and lowest in the pig, and this is probably accounted for by the amounts of hair possessed by these animals. It is known that hair contains more $\mathrm{Zn}$ than most other biological material (Lutz, 1926; Eggleton, 1939), and the cat, the only species of the four which is not born naked, had the highest percentage of $\mathrm{Zn}$ in its body at birth. Analyses were made of the $\mathrm{Zn}$ in the coverings of four different classes of mammals ('Table 7 ), and there seems to be no doubt that the epidermal structures contain a particularly high concentration of $\mathrm{Zn}$. In the rat and hedgehog $38 \%$ of the $\% \mathrm{n}$ in the whole animal was situated in the skin and hair or bristles. It seems likely that in other species with much fur or wool the epidermal structures may contain an even larger proportion. Exactly how the $\mathrm{Zn}$ is attached to the proteins in the keratin is not known, nor can we say whether it performs any useful function there. It seems unlikely that it 
Vol. 4

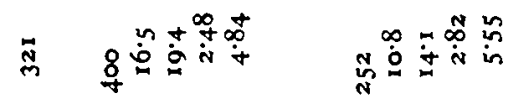

年

8

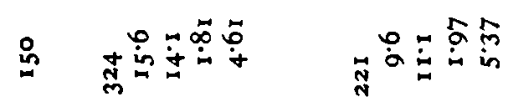

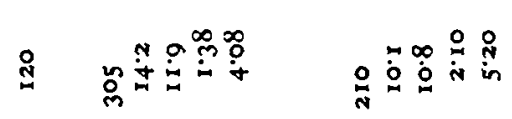

¿ \&

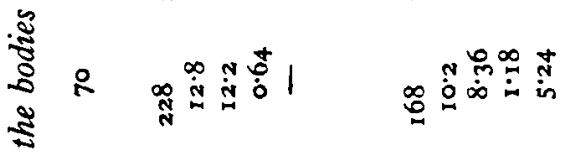

홍

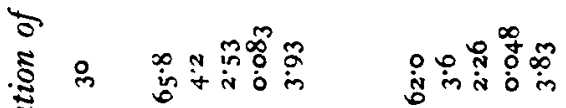

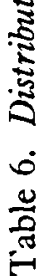

㺼

苟

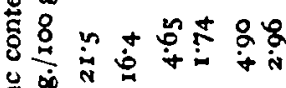

药

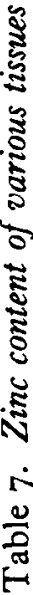

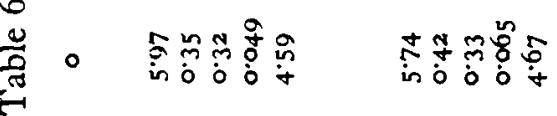

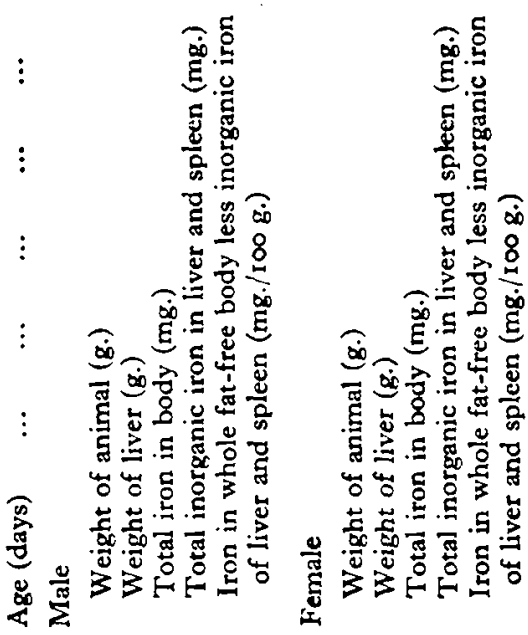

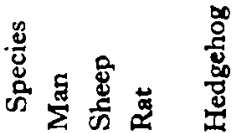


could ever find its way into the body again to take part in the enzyme systems and it is interesting to consider how much $\mathrm{Zn}$ is shorn off a sheep each time it is sheared. Assuming that $8 \mathrm{lb}$. of wool are removed at each shearing, this might contain about $600 \mathrm{mg}$. $\mathrm{Zn}$.
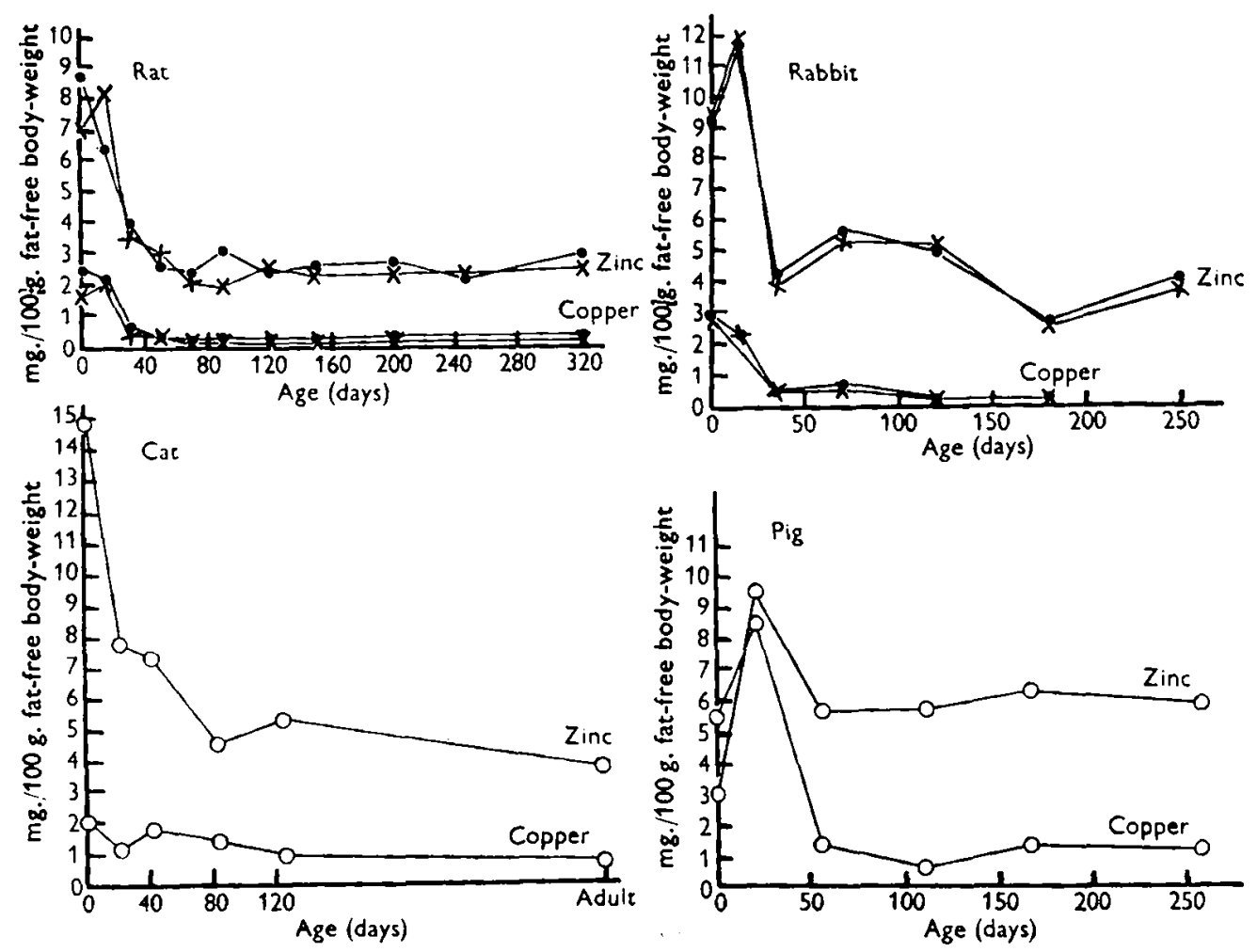

Fig. 7. Effect of age on the concentrations of zinc and copper in liver tissue of rats, cats, rabbits and pigs. $\times-x$, males; -0 , females; $O-O$, males and females mixed. 'Table I gives the number of animals on which values are based.

The concentrations of $\mathrm{Zn}$ in the livers and spleens of the animals are shown in Fig. 7 . In newborn rats and rabbits these organs contained 7-9 mg./ $100 \mathrm{~g}$. and the concentration tended to rise during suckling. In both species the concentration fell abruptly after weaning to about one-third of its highest value and it never rose again significantly. Kittens were born with $15 \mathrm{mg}$. $\mathrm{Zn} / \mathrm{roO} \mathrm{g}$. in the liver but this concentration was not maintained. 'The adult concentration was approximately that found by Lutz (1926), namely $4 \mathrm{mg} . / 100 \mathrm{~g}$. The pig differed from the other species in that the concentration of $\mathrm{Zn}$ in the liver was only $3 \mathrm{mg}$./100 g. at birth. It rose during suckling and fell again afterwards to the adult level of about $6 \mathrm{mg} / \mathrm{s} 00 \mathrm{~g}$. The only change, therefore, common to all four species was the decided fall in concentration when mixed feeding began, and it is interesting that this fall was not obvious in the series of human livers analysed by Widdowson et al. (195I).

Copper. Fig. 8 shows the results obtained for the concentration of $\mathrm{Cu}$ in the whole bodies of the animals. In the rat there was a small rise during suckling to $0.5 \mathrm{mg} / 100 \mathrm{~g}$., 
followed by a prolonged slow fall to $0.13 \mathrm{mg}$. $/ 100 \mathrm{~g}$. at $210-240$ days and a return to $0.21 \mathrm{mg} . / 100 \mathrm{~g}$. at 320 days. These results from weaning onwards constitute a most satisfactory confirmation of those of Lindow et al. (1929). An interrelationship of $\mathrm{Fe}$ and $\mathrm{Cu}$ is suggested when the two sets of curves are considered together. Sachs, Levine, Hill \& Hughes (1943) showed that the amount of $\mathrm{Cu}$ in human blood varies inversely with $\mathrm{Fe}$ at all ages, and this phenomenon is apparently true for the total
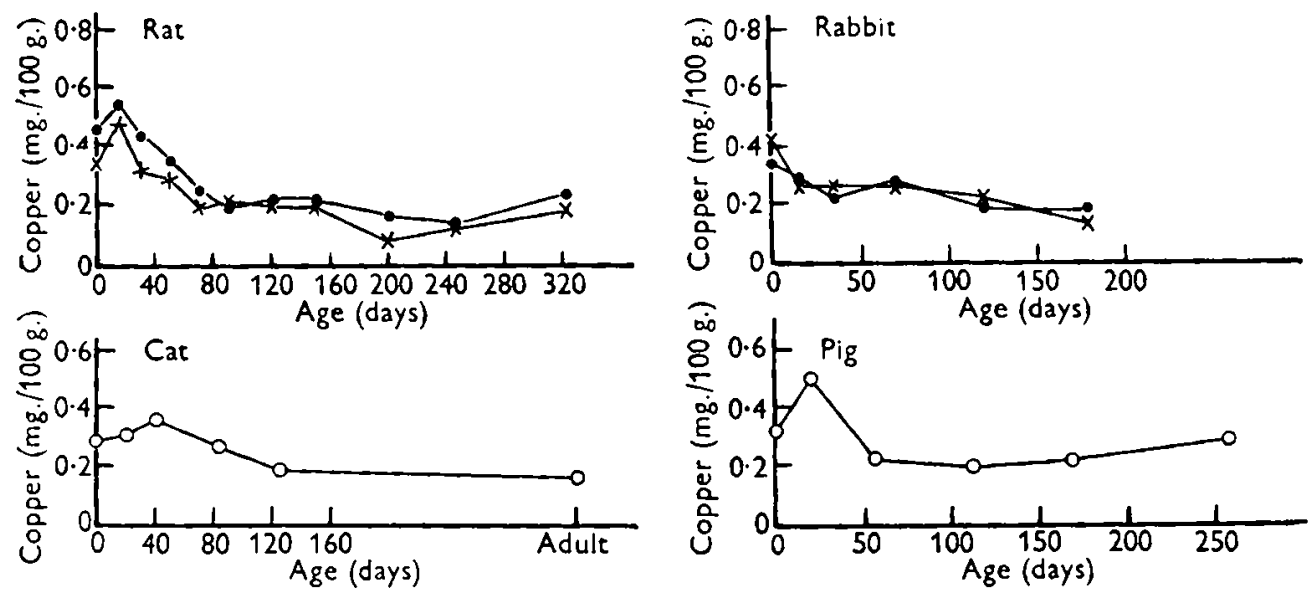

Fig. 8. Effects of age on the concentrations of copper in fat-free body tissue of rats, cats, rabbits and pigs. $\times-x$, males; -0 , females; $\bigcirc-O$, males and females mixed. Table I gives the number of animals on which values are based.

amounts of $\mathrm{Fe}$ and $\mathrm{Cu}$ in the rat's body. In the other three species the concentration of copper also decreased throughout growth from weaning onwards and in all cases the amount in the adult approximated to $0.2 \mathrm{mg} . / 100 \mathrm{~g}$. There was no striking sex difference, although female rats almost always had slightly greater concentrations than males of the same ages.

The concentrations of $\mathrm{Cu}$ found in the livers and spleens are shown in Fig. 7. In all four species the concentration was highest at birth or during suckling and then decreased at or after weaning to a fairly constant adult level. Cunningham (1931) also found much lower concentrations of $\mathrm{Cu}$ in the livers of adult pigs, guinea-pigs, rabbits and rats than in the corresponding newborn animals, and Brückmann \& Zondek (1939) and Widdowson et al. (1951) obtained essentially the same result for man. Lorenzen \& Smith (1947) described a fall in the percentage after weaning in the rat, but found the highest concentration in the livers of adult rabbits and guinea-pigs. In the present study an increase from $0.4 \mathrm{r}$ to $0.5 \mathrm{r} \mathrm{mg}$. Cu/roo g. of fresh liver in male rabbits and from 0.40 to $0.67 \mathrm{mg}$./100 g. in females was observed between 35 and 70 days, but at the older ages a definite decrease took place.

\section{The effect of giving iron to piglets during suckling on the composition of their bodies at 3 weeks}

Table 8 shows that the animals that had had Fe were not bigger because they were fatter. Two of the three had in fact a smaller percentage of fat in their bodies than their 
Table 8. The effect of iron given to piglets during suckling on the composition of their bodies at 3 weeks

Weight at 3 weeks (g.)

Water (g./100 g.)

Protein (g.j/ $100 \mathrm{~g}$.)

Fat (g./ $/ 00 \mathrm{~g}$.)

Sodium (mg./100 g.)

Potassium (mg./100 g.)

Calcium (mg. $/ 100 \mathrm{~g}$.

Magnesium (mg./100 g.)

Phosphorus (mg./roo g.)

Iron (mg./100 g.)

Copper (mg./100 g.)

Zinc (mg./roo g.)
Piglets given iron

$\begin{array}{ccc}\text { Litter X } & \text { Litter Y } & \text { Litter Z } \\ 7450 & 6400 & 9600 \\ 66 \cdot 5 & 74 \cdot 3 & 65 \cdot 9 \\ 13 \cdot 5 & 13 \cdot 9 & 13 \cdot 7 \\ 17 \cdot 1 & 9 \cdot 0 & 17 \cdot 6 \\ 135 & 157 & 117 \\ 212 & 252 & 224 \\ 839 & 750 & 782 \\ 31 \cdot 1 & 31 \cdot 1 & 26 \cdot 3 \\ 488 & 492 & 463 \\ 5 \cdot 46 & 2 \cdot 93 & 3 \cdot 32 \\ 0.49 & 0.52 & 0.31 \\ 1 \cdot 29 & 1 \cdot 50 & 1 \cdot 43\end{array}$

Litter-mates not given iron

\begin{tabular}{ccc}
\hline Litter X & Litter Y & Litter Z \\
5782 & 5500 & 9500 \\
69.5 & 68.0 & 57.9 \\
12.8 & 13.7 & 11.5 \\
14.9 & 15.6 & 27.6 \\
163 & 133 & 128 \\
245 & 237 & 210 \\
753 & 765 & 829 \\
26.7 & 32.4 & 29.4 \\
488 & 458 & 520 \\
1.29 & 1.79 & 1.53 \\
0.47 & 0.47 & 0.28 \\
1.03 & 1.57 & 1.14
\end{tabular}

litter-mates that had not been given Fe. A 3-week-old piglet from another litter, which had been reared outside on grass, with free access to soil (Venn et al. 1947, Table VIII) had only $14.3 \%$ of fat, in spite of the fact that it had grown very well and had $5.76 \mathrm{mg}$. Ie/ $/ 100 \mathrm{~g}$. of its body-weight.

The three piglets that had received Fe had slightly more protein per $\mathrm{I} 00 \mathrm{~g}$. than their litter-mates that had not been given $\mathrm{Fe}$, and it is evident that their rapid growth consisted of a laying down of protein rather than of fat. The concentrations of all the inorganic constituents other than Fe were very similar whether the piglet had received Fe or not. It must be concluded, therefore, that the anaemia reduced the size of the animal without altering its composition.

\section{DISCUSSION}

The differences and similarities in the chemical composition of various species of mammals at birth have been discussed by Widdowson (1950). 'The present investigation provides an opportunity for making similar comparisons at later stages of development. Moulton (1923) considered that 'chemical maturity' is reached in the rat at 50 days, in the cat at about 100 days and in the pig at 150-300 days. No prediction was made for the rabbit because of lack of information about its chemical composition. If Moulton's figures are compared with the approximate age of puberty in the different species (T'able 2) it will be seen that by his reckoning the pig does not reach a mature composition until after puberty, whereas the cat is chemically mature long before.

The results of the present investigation have shown that the concentration of some of the constituents of the body goes on increasing after that of others has ceased to do so. 'The date of chemical maturity based on the potassium calendar, for example, would be much earlier than if the reckoning were based on calcium. The term 'chemical maturity' can only be applied to the body as a whole when all its constituents have reached a constant level. 'The adults of one species, however, may fairly be compared with those of another, and often the general conclusions are quite clear. More than $50 \%$ of the body of the adult pig (Callow, 1948) may consist of fat, but there is no evidence 
that the rat, rabbit or cat ever achieves this proportion. Man, however, must be considered quite as 'fat' an animal as the pig, since McCance \& Widdowson (195 I $b$ ) have found over $50 \%$ of adipose tissue in some obese people. Table 9 shows the approximate percentage composition of the adult rat, rabbit and cat on a fat-free basis, and figures for a human adult of 'normal' weight for height (Widdowson et al. I95 I) have been added for comparison. Values for the pig are also shown, but these apply to animals that were still rapidly growing although they had long since reached sexual maturity.

Table 9. Comparison of the chemical composition of adult animals, including man (All results expressed per $100 \mathrm{~g}$. of fat-free body tissue)

Weight (kg.)
Protein (g.)
Water (g.)
Sodium (mg.)
Potassium (mg.)
Calcium (mg.)
Magnesium (mg.)
Phosphorus (mg.)
Iron (mg.)
Copper (mg.)
Zinc (mg.)

$\begin{array}{ccccc}\text { Rat } & \text { Rabbit } & \text { Cat } & \text { Pig } & \text { Man } \\ 0.35 & 2.6 & 4.0 & 125 & 65 \\ 22.1 & 23.2 & 21.0 & 19.6 & 19.4 \\ 73.7 & 72.8 & 74.4 & 75.6 & 72.8 \\ 150 & 150 & 150 & 150 & 217 \\ 300 & 300 & 300 & 280 & 280 \\ 1300 & 1300 & 1300 & 1200 & 2305 \\ 40.0 & 50.0 & 45.0 & 45.0 & 45.5 \\ 700 & 700 & 800 & 700 & 1345 \\ 6.0 & 6.0 & 6.0 & 9.0 & 7.4 \\ 0.2 & 0.15 & 0.15 & 0.25 & 0.17 \\ 3.0 & 5.0 & 2.3 & 2.5 & 2.8\end{array}$

Man has the least protein and potassium and the rabbit the most, but man, on the other hand, has more sodium per $100 \mathrm{~g}$. of fat-free tissue than any of the other four species. Calcium and phosphorus were also highest in man and the explanation undoubtedly is that the skeleton comprises about $17.5 \%$ of the adult human body (Shohl, 1939) in contrast to I $1 \%$ of the adult rat's (Donaldson, 1924) and $7.7 \%$ of the 28 -week-old pig's (McMeekan, 1940). 'This probably also explains the large amounts of sodium in the human body, since bones contain far more sodium than potassium. Harrison, Darrow \& Yannet (1936), moreover, working with rabbits, dogs and monkeys, have shown that half the sodium in the body is in bone and cartilage and that nearly half of this is combined in some insoluble form.

It must be concluded that, though the idea of chemical maturity has been valuable, it requires elaboration and further definition if it is to be used for detail. The composition of the fat-free body tissue of adult animals of various species is similar, but there are real differences and these may be as important as the similarities.

\section{SUMMARY}

I. 'The concentrations of protein, water, fat, sodium, potassium, calcium, magnesium, phosphorus, iron, copper and zinc in the bodies and livers and spleens of rats, rabbits, cats and pigs have been followed from birth to maturity. Mice and guinea-pigs have also been studied during the early part of their lives.

2. The results are discussed in relation to Moulton's (1923) conception of chemical maturity. It is concluded that though this is valuable, it is not a true generalization, and requires elaboration if it is to be applied in detail. 
3. For the rat and rabbit the sexes were studied separately and a number of differences established. For example, from puberty or soon afterwards the females of both species were always fatter than the males and they had a higher concentration of iron. Female rats contained more calcium than males, but this difference was not so apparent in the rabbit.

4. 'I he values for the composition of the adults of the four species studied have been compared and contrasted with corresponding figures for man.

5. Human hair, sheep's wool, rat's skin and hair and hedgehog's skin and bristles were shown to contain zinc in high concentrations.

We should like to express our thanks to $\mathrm{Mr} \mathrm{J}$. A. J. Venn for his co-operation over the pigs, and to Mrs P. Westley for all the care she has expended on the smaller animals.

\section{RFFHRENCES}

Bertrand, G. \& Brandt-Beauzemont, Y. (1931). Bull. Soc. Chim. biol., Paris, I3, 197.

Bessey, O. A., King, C. G., Quinn, E. J. \& Sherman, H. C. (1935). F. biol. Chem. rri, 1 I5.

Braude, R. \& Foot, S. A. (1946). Vet. F. 102, 71.

Briggs, A. P. (1922). F. biol. Chem. 53, 13 .

Briwa, K. E. \& Sherman, H. C. (1941). F. Nutrit. 21, I55.

Brody, S. (1927). Res. Bull. Mo. agric. Exp. Sta. no. 102.

Brückinann, G. \& Zondek, S. G. (1939). Biochem. F. 33, I845.

Buckner, G. D. \& Peter, A. MI. (1922). F. biol. Chem. 54, 5 .

Bunge, G. (1889). Hoppe-Seyl. Z. 13, 399.

Bunge, G. (1892). Hoppe-Seyl. Z. 16, 173 .

Burns, C. M. \& Henderson, N. (1936). Biochem. F. 30, 1207.

Callow, E. H. (1947). F. agric. Sci. 37, 113 .

Callow, E. H. (1948). Ұ. agric. Sci. $3^{8}, 174$.

Carttar, M. S., McLean, F. C. \& Lrist, M. R. (1950). Amer. F. Path. 26, 307.

Chanutin, A. (1931). F. biol. Chem. 93, 31.

Cox, W. M. Jr. \& Imboden, M. (1936). F. Nutrit. Ir, 177.

Cunningham, I. J. (I 93 I). Biochem. $\mathscr{f} .25$, I 267.

Deuel, H. J. Jr., Hallman, L. F., Movitt, E., Mattson, F. H. \& Wu, E. (1944). F. Nutrit. $27,335$.

Donaldson, H. H. (1924). The Rat. Philadelphia: The Wistar Institute.

Drinker, K. R., Thompson, P. K. \& Marsh, M. (r 927). Amer. Y. Physiol. 8o, 31 .

Eden, A. \& Green, H. H. (1940). Biochem. F. 34, 1202.

Eggleton, W. G. E. (1939). Biochem. Y. 33, 403.

Ellis, N. R. \& Hankins, O. G. (1925). Y. biol. Chem. 66, 101.

Fairhall, I. T'. (1926). 7. biol. Chem. 70, 495 .

Foot, S. A. \& 'Thompson, S. Y. (1938). F. Minist. Agric. 45, 452.

Foot, S. A. \& Thompson, S. Y. (1947). Э. Minist. Agric. 54, 308.

Haminct, F. S. (1925). \%. biol. Chem. 64, 409 .

Hammond, J. (1932). Groith and the Derelopment of Mutton Qualities in the Sheep. Edinburgh: Oliver and Boyd.

IHarrison, M. F. (1951). Biochem. F. 48, 283.

Harrison, H. E., Iarrow, D. C. \& Yannct, II. (1936). F. biol. Chem. 113, 5 I5.

Hatai, S. (1917). Amer. F. Anet. 21, 23.

Houk, A. E. H., 'Thomas, A. W. \& Sherman, H. C. (1946). F. Nutrit. 3r, 609.

Hubbell, R. B. \& Mendel, L. B. (1927). F. biol. Chem. 75, 567 .

Hubbell, H. J. \& Rose, M. S. (1937). F. Nutrit. 13, Suppl., p. 8.

Huggett, A. St G. \& Widdas, W. F. (1949). F. Physiol. r 10, 386.

Hutchinson, J. C. D. (1947a). Brit. F. Nutrit. 1, 219.

Hutchinson, J. C. D. (1947b). Brit. F. Nutrit. I, 23 I.

Hutchinson, J. C. D. \& Baker, C. J. I.. (1949). Brit. F. Nutrit. 3, 12.

Inaba, R. (гg I). Arch. Anat. Physiol., Lpz., Physiol. Abt. p. I.

Keilin, D. \& Mann, T. (1940). Biochem. F. 34, $1 \times 63$.

Lanford, C. S., Campbell, H. L. \& Sherman, H. C. (r941). F. biol. Chem. r37, 627.

Lindow, C. W., Peterson, W. H. \& Steenbock, H. (1929). F. biol. Chem. 84, 419. 
Lintzel, W. \& Radeff, T. (1931). Arch. Tierernähr. Tierz. 6, 313.

Lorenzen, E. J. \& Smith, S. E. (1947). F. Nutrit. 33, 143.

Lowrey, L. G. (1913). Anat. Rec. 7, 143.

Lutz, R. E. (1926). J. industr. Hyg. 8, 177 .

McCance, R. A. (1944). Biochem. F. 38, 474 .

McCance, R. A. \& Shipp, H. L. (1933). Spec. Rep. Ser. med. Res. Coun., Lond., no. I87.

McCance, R. A. \& Widdowson, E. M. (1951 a). F. Physiol. 112, 450.

McCance, R. A. \& Widdowson, E. M. (195 I b). Proc. Roy. Soc. B, 138, I 5.

McCance, R. A., Widdowson, E. M. \& Shackleton, L. R. B. (1936). Spec. Rep. Ser. med. Res. Coun., Lond., no. 213.

McMeekan, C. P. (1940). Y. agric. Sci. 30, 276.

McMcekan, C. P. (1941). F. agric. Sci. 31, I.

Mitchell, H. H. \& Hamilton, T. S. (1929). Bull. Ill. agric. Exp. Sta. no. 323.

Morgulis, S. (1931). F. biol. Chem. 93, 455 .

Moulton, C. R. (1923). F. biol. Chem. 57, 79 .

Moulton, C. R., Trowbridge, P. F. \& Haigh, L. D. (1922). Res. Bull. Mo. agric. Exp. Sta. no. 55 .

Murray, J. A. (1922). F. agric. Sci. 12, 103.

Newell, J. M. \& McCollum, E. V. (1933). F. Nutrit. 6, 289.

Otis, L. \& Smith, M. C. (1940). Science, 91, 146.

Outhouse, J. \& Mendel, L. B. (1933). F. exp. Zool. 64, 257.

Pálsson, H. (1939). F. ayric. Sci. 29, 544.

Pálsson, H. (1940). F. agric. Sci. 30, I.

Sachs, A., Levine, V. E., Hill, F. C. \& Hughes, R. (1943). Arch. intern. Med. $71,489$.

Scott, E. L. (1930). Bull. Ind. agric. Exp. Sta. no. 340.

Shackleton, L. \& McCance, R. A. (1936). Biochem. F. 30, 582 .

Sheline, G. E., Chaikoff, I. L., Jones, H. B. \& Montgomery, M. L. (1943). F. biol. Chem. $149,139$.

Sherman, H. C. \& Bwoher, L. E. (1931). Y. biol. Chem. 93, 93.

Sherman, H. C. \& MacLeod, F. L. (1925). F. biol. Chem. 64, 429.

Sherman, H. C. \& Quinn, E. J. (1926). F. biol. Chem. 67, 667.

Shohl, A. T. (1939). Mineral Metabolism. New York: Reinhold Publishing Corporation.

Smythe, C. V. \& Miller, R. C. (1928-q). F. Nutrit. I, 209.

Steenbock, H., Semb, J. \& Van Donk, E. C. (1936). F. biol. Chem. r14, ci.

Thomas, K. (I91 1). Arch. Anat. Physiol., Lpz., Physiol. Abt. p. 9.

Venn, J. A. J., McCance, R. A. \& Widdowson, E. M. (1947). F. comp. Path. 57, 3 I4.

von Bezold, A. (1857). Z. wiss. Zool. 8, 487 .

von Bezold, A. (1858). Z. wiss. Zool. 9, 240.

von Lieberman, L. \& Szekely, S. (1898). Pfligg. Arch. ges. Physiol. 72, 360.

Widdowson, E. M. (1950). Nature, Lond., 166, 626.

Widdowson, E. M. \& McCance, R. A. (1948). Biochem. F. 42, 577.

Widdowson, E. M., McCance, R. A. \& Spray, C. M. (I95I). Clin. Sci. (In the Press.)

Widdowson, E. M. \& Spray, C. M. (1951). Arch. Dis. Childh. (In the Press.)

Zucker, T. F. \& Zucker, L. M. (1946). Amer. F. Physiol. 146, $5^{85}$. 